(C) 2015

Бердник В. П., доктор ветеринарних наук, Бублик О. О., кандидат ветеринарних наук, Бердник І. Ю., кандидат біологічних наук, Щербак В. І., старший викладач

Полтавська державна аграрна академія

\title{
ЗАСОБИ І МЕТОДИ СПЕЦИФІЧНОЇ ПРОФІЛАКТИКИ МІКОПЛАЗМОЗУ СВИНЕЙ
}

\section{Рецензент - доктор ветеринарних наук Б. П. Киричко}

Стаття присвячена вивченню методів специфічної профілактики мікоплазмозу свиней в Украӥні. Результати численних досліджень показують, щзо в господарствах України збудниками мікоплазмозу свиней (МC) частіше всього є M. hyorhinis, M. arginini, M. hyosynoviae i pidue M. hyopneumoniae ma Acholeplasma ( A.) laidlawii. Звідси виходить, щчо вакцини треба готувати із застосуванням штамів названих видів мікоплазм і ахолеплазми. Застосування вакцин $з$ інактивованих збудників мають значно нижчу ефективність у порівнянні з неінактивованими вакцинами, які вводять у дихальні шляхи.

Ключові слова: специфічна профілактика, мікоплазма, вакиина, поросята, сисуни, свиномат$\kappa и$, мікробіологічні методи дослідження.

Постановка проблеми. Вакцини 3 інактивованих збудників мікоплазмозу птиці, щеплені парентерально, мали низьку ефективність через індукцію гомологічних антитіл переважно у крові, а не в слизовій оболонці дихальних шляхів, яка $\epsilon$ воротами інфекції. Тому зараз у птахівництві перевагу віддають неінактивованим вакцинам, які вводять у дихальні шляхи.

У США і деяких країнах Європи вважають, що збудником ензоотичної пневмонії (мікоплазмозу) свиней є лише Mycoplasma (M.) hyopneumoniae. Тому з їі культур готують за певними технологіями комерційні інактивовані вакцини (гіобактерини) і вже майже 10 років реалізують у свинарських господарствах цих країн і навіть в Україні [4, 11-13]. Їх рекомендують вводити у м'язи чи підшкірно. Рідше є публікації про введення в носову порожнину живих вакцин із цього збудника $[8,9]$.

Результати численних досліджень показують, що в господарствах України, Росії, Білорусії i Казахстану збудниками мікоплазмозу свиней (MC) найчастіше $€ \mathrm{M}$. hyorhinis, M. arginini, M. hyosynoviae i piдше M. hyopneumoniae та Acholeplasma (А.) laidlawii [1-7]. Звідси виходить, що вакцини треба готувати із застосуванням штамів названих видів мікоплазм і ахоле- плазми. Результати випробування такої 5-валентної вакцини в умовах лабораторії показали перспективність вибраного напряму щодо пошуку засобів і методів боротьби з мікоплазмозом свиней [4].

Аналіз основних досліджень i публікацій, у яких започатковано розв'язання проблеми. Детальний аналіз основних публікацій щодо вирішення проблеми специфічної профілактики MC та дослідження в лабораторних умовах нами також установлено, що щеплення в носову порожнину вакцини 3 атенуйованих штамів п'яти видів мікоплазм викликало у поросят-сисунів перебудову до них клінічних, біохімічних та імунологічних показників, як до генетично чужого фактору. У них, порівняно із контролем, виявили значно менший ступінь ураження легень серозно-катаральним запаленням після контрольного зараження епізоотичними культурами мікоплазм чи суспензією нативного матеріалу в середньому у 16 і 2 рази та частоту виділення бактерій до $7,1 \%$ i 83,3\% відповідно. У 5місячному віці щеплені поросята, порівняно 3 контролем, мали більшу на 2,3-2,4 кг середню живу масу тіла. Серед них була менша на 2,17,6 \% частота загибелі. Наведені дані дають підстави до випробування названої вакцини в умовах свинарських господарств, неблагополучних щодо МС.

Мета досліджень - приготувати і випробувати вакцину $з$ атенуйованих штамів чотирьох видів мікоплазм і одного виду ахолеплазми у трьох свинарських господарствах та вакцин із «місцевих штамів», тобто виготовлених із культур мікоплазм, виділених із легень свиней, уражених серозно-катаральним запаленням, двох господарств, неблагополучних щодо МС.

Завдання: 3 атенуйованих штамів мікоплазм, виготовити зразки вакцини та випробувати в умовах господарства неблагополучних по мікоплазмозу.

Методика проведення досліджень. П'ятивалентну МВ готували так як описано за методикою (4). Вакцину із «місцевих штамів» міко- 


\section{ВЕТЕРИНАРНА МЕДИЦИНА}

плазм та Bordetella (B.) bronchiseptica готували згідно з методиками, що викладені нижче у відповідному підрозділі.

Результати досліджень. 1. Спеціалізоване господарство 1 на 12000 свиней в обороті за один рік.

У досліді 1 було 146 поросят, яким щепили 5-валентну МВ два рази в носову порожнину i третій раз у м'язи з інтервалом 12 і 20 діб в дозах 1 мл, 3 і 5 мл відповідно. Загальна доза становила $1,14.10^{9}$ колонісутворюючих одиниць (КУО) мікоплазм. У контролі було 163 поросят, яким вводили рідке поживне середовище для мікоплазм (РПСМ) за аналогічною схемою. Перше щеплення робили поросятам 13-19-добового віку.

В досліді 2 було 187 поросят-сисунів, із яких сформували 7 груп (2 контрольних) по 23-31 поросяті. Поросятам першої і другої груп із 32добового віку щепили МВ з інтервалами 7 і 30 та 14 і 30 діб відповідно (загальна доза 2,12+$0,2.10^{9}$ КУО мікоплазм), четвертої і п'ятої групи з 20-добового - через 7 і 49 діб та шостої групи iз 20-добового - через 30 і 26 діб (загальна доза 1,24+-0,14.109 КУО мікоплазм). У контрольних групах 3 i 7 поросятам вводили РПСМ із інтервалами 14 і 30 діб та 30 і 26 діб відповідно. Дози МВ чи плацебо були 3 мл, 5 і 5 мл.

Після другого-третього щеплень МВ у поросят досліду 1 спостерігали ознаки підвищеної активності захисних механізмів - статистично вірогідне збільшення ШОЕ, кількості загального білку в сироватці крові, еритроцитів, гемоглобіну та лейкоцитів у периферійній крові за рахунок еозинофілів, лімфоцитів, сегментоядерних (друге щеплення) та паличкоядерних (третє щеплення) нейтрофілів, продукцію гомологічних комплементзв'язуючих антитіл (К3 - антитіл) та аглютинінів до титрів 1:5 - 1:40. У поросят, що були на контакті із хворими на мікоплазмоз упродовж 40-70 діб після останнього щеплення вакцини, після забою виявили серозно-катаральне запалення легень із ураженням 25,1+-2,1 \% їх поверхні проти 49,8+-1,1\% у контрольних. За 5 місяців досліду 1 у щеплених поросят, порівняно 3 контрольними, були більшими середня жива маса тіла, збереженість і показники технологічності на 3,0 кг, 7,6 і 25,5 \% відповідно.

У досліді 2 із п'яти випробуваних схем кращі результати одержали в разі щеплення вакцини поросятам із 32-добового віку два рази із 7-добовим інтервалом в носову порожнину i один раз через 38 діб - у м’язи (група 1) та із 20добового за такою ж схемою, але із інтервалом 7 та 49 діб (група 4). Порівняно 3 контролями, поросята групи 1 мали вірогідно більші показники середньої живої маси тіла, збереженості і технологічності на 2,8 кг, 9,4 і 28,4\%, а групи 4 - на 3,3 кг, 5,6 та 31,3 \% відповідно. У поросят груп 2,5 і 6 ці показники були нижчими. Крім того, поросят груп 5 і 6 загинуло навіть на 6,7 та 2,9\% більше, ніж у контролі. В цьому досліді ще раз підтверджено, що поросятам краще щеплювати вакцину із 20-32-добового віку (3-4-тижневого віку). Інтервал між введенням вакцини в носову порожнину повинен становити 7 діб, а не 14 (у групі 2) чи 30 (у групі 6).

2. Спеціалізоване господарство 2 на 12000 свиней в обороті за один рік.

МВ випробували на поросятах-сисунах у двох дослідах. У досліді 1 ïi щепили 381 поросяті із 12-добового віку, а в досліді 2-176 поросятам із 8-добового (у контролях було 184 та 194 поросят відповідно) - два рази з інтервалом 7-8 діб у носову порожнину і один раз через 40-50 діб - у м'язи в дозах 3 мл, 4 та 5 мл відповідно. Всього кожне порося одержало по $3,0.10^{9}$ КУО мікоплазм. Щеплених і контрольних поросят утримували поруч зі станками, в яких були хворі на мікоплазмоз тварини (контактне зараження). За поросятами встановили постійне клінічне спостереження до передачі на відгодівлю (5-6місячного віку) і періодично їх зважували. Їх відняли від свиноматок в 45-добовому віці і передавали на дорощування в 60-65-добовому віці. Поросят, які з якихось причин гинули, досліджували за допомогою патологоанатомічного, бактеріологічного та мікоплазмологічного методів. У 5-місячному віці передали на відгодівлю щеплених поросят, порівняно із контролем, більше на 7,6-14,8 \% із більшою живою масою тіла на 2,32,4 кг, а загибель серед них, навпаки, була меншою на 2,1-7,6 \%.

Таким чином, у господарствах, де віднімають поросят від свиноматок у 45-добовому віці, кращою є схема щеплення, за якою перший і другий раз 3 інтервалом у 7-8 діб вводять МВ у носову порожнину, а втретє через 40-50 діб - у м'язи. Клінічні, патологоанатомічні та серологічні дослідження показали, що щеплення МВ запобігало масове зараження епізоотичними культурами мікоплазм поросят 45-60-добового віку в період стресу, викликаного відняттям від матері та пристосуванням до нових умов життя.

3. Спеціалізоване господарство 3 на 12000 свиней в обороті за один рік.

У досліді випробували щеплення свиноматок та їх поросят МВ в комплексі 3 вакциною із B. bronchiseptica (БВ). В одній групі було 15 свиноматок, яким щепили БВ за 40-45 та 15-20 діб до опоросу, і їх 117 поросятам, з яких 39 ще- 


\section{ВЕТЕРИНАРНА МЕДИЦИНА}

пили МВ, 25 - БВ, 28 - МВ+БВ і 25 - плацебо (контроль). У другій групі було 29 нещеплених БВ свиноматок і їх 242 поросят, із них 104 щепили МВ, 51 - БВ, 53 - МВ+БВ і 34 - плацебо (контроль). МВ вводили поросятам із 8-12добового віку два рази в носову порожнину (а БВ - одночасно, але в м'язи) і один раз у м'язи із 7-8 та 40-50-добовими інтервалами в дозах 3 мл, 4 та 5 мл відповідно. Всього поросятам ввели $3,0.10^{9}$ КУО мікоплазм. БВ вводили поросним свиноматкам у дозах по 5 та 10 мл, а поросятам iз 8-12-добового віку - два рази із 7-8-добовим інтервалом, як і MB, але у м'язи по 2 та 3 мл.

МВ готували із культур штамів та видів мікоплазм, як і в лабораторних дослідах, а БВ - iз культури штаму К - 5 В. bronchiseptica, виділеного від поросяти цього ж господарства. Для виділення із патологічного матеріалу, культивування і атенуації культуру В. bronchiseptica пересівали до 30 разів із 2-4-добовим інтервалом в порівняльному аспекті на агарі Борде-Жангу із добавкою до 1,0 \% гліцерину і $20 \%$ дефібринованої крові вівці, у тріптозо-фосфатному бульоні (10) та середовищі для мікоплазм на основі бульону Мартена без оцтовокислого таллію (2-3), в яке додавали до $5 \%$ сироватки крові великої рогатої худоби та $2 \%$ екстракту дріжджів із $\mathrm{pH}$ 7,8. Як вакцину брали свіжовирощену бульонну 2-4-добову культуру цього мікроорганізму. Її перевіряли на специфічність росту, відсутність забруднення іншими бактеріями та нешкідливість для білих мишей (2-4).

Через 7-10 діб після третього щеплення вакцин у 10 поросят із кожної дослідної групи відібрали проби крові. Їх дослідили в реакції аглютинації (РА) та реакції тривалого зв'язування комплементу в мікрооб'ємі (РТЗКМ) із антигенами всіх видів молікутів, які застосували для виготовлення вакцини, та B. bronchiseptica. Щеплених і контрольних поросят утримували поруч зі станками, в яких були хворі на мікоплазмоз тварини (контактне зараження).

Поросят відняли від свиноматок у 45добовому віці і передавали в групу дорощування в 60-65-добовому. Ефективність вакцинації оцінювали із врахуванням технологічних показників (збереженість, кількість переданих на відгодівлю в технологічний термін, жива маса тіла) поросят до 5-6-місячного віку та результатів клінічних, патологоанатомічних, серологічних, бактеріологічних та мікоплазмологічних досліджень.

Порівняно з контролем, поросят від щеплених БВ свиноматок, щеплених МВ та МВ + БВ передано на відгодівлю більше на 8,6 та 9,7 \% із більшою на 3,5, 3,9 кг середньою живою масою тіла відповідно. Їх збереженість також була вищою на 5,4 та 0,9 \%. Після щеплення БВ у поросят спостерігали лише більшу на 1,1 кг живу масу тіла.

Поросят від нещеплених БВ свиноматок, щеплених МВ, МВ+БВ і БВ передано на відгодівлю більше на 13,9 \%, 14,1 і 7,8 \% із більшою живою масою тіла на 4,5 кг, 4,4 і 2,0 кг відповідно. Їх збереженість також була вищою на 4,0 \%, 3,1 i 1,0\% відповідно.

За період дослідів загинуло 16 поросят-сисунів та 6 на дорощуванні.

Серед них від щеплених БВ свиноматок було 6 сисунів і один із групи дорощування, а від нещеплених - 10 і 5 відповідно. Їх виявили у кожній із 8 підгруп досліду без певної закономірності. На розтині у всіх поросят-сисунів виявили катаральне запалення слизової оболонки дна шлунку та тонкого кишечнику і у двох (щепленого БВ та контрольного ) - ділянки серознокатарального запалення розміром $1 \times 1,5$ cм на правій та лівій верхівкових частках легень. Iз їх внутрішніх органів виділили культури В. bronchiseptica, Escherichia (E.) coli, Pseudomonas aerugynosa, St.aureusta Proteus mirabilis. Iз уражених запаленням легень поросят ізолювали культури M. hyorhinis, M. arginini i Staphylococcus (St.) aureus. На розтині у поросят із групи дорощування спостерігали катаральний гастроентерит, а в обох контрольних - також ділянки серозно-катарального запалення розміром $0,3 \times 0,6 \mathrm{~cm}$ на правих верхівкових та серцевих частках легень. Iз їх органів ізолювали культури М. hyorhinis, B. bronchiseptica, St.aureus та Е.coli. Під час серологічних досліджень виявили гомологічні аглютиніни до мікоплазм (1:10-1:20) і бордетел $(1: 10-1: 80)$ та К3 - антитіла до мікоплазм $(1: 5-1: 40)$.

Показники збереженості, кількості переданих на відгодівлю та живої маси тіла були найвищими у поросят, одержаних від нещеплених БВ свиноматок, і щеплених МВ та МВ + БВ. Не виявили суттєвої різниці в названих показниках поросят, щеплених МВ та МВ + БВ, що в даному випадку свідчить за недоцільність щеплень БВ.

У поросят від щеплених БВ свиноматок і також щеплених проти цього захворювання лише один із трьох показників - жива маса тіла була вищою проти контролю, а від нещеплених - всі три. Це показує, що щеплення БВ треба робити поросятам із 8-20-добового віку, яких одержують від свиноматок, нещеплених проти цього захворювання.

Виявлення антитіл до мікоплазм і бордетел у крові контрольних поросят, а також уражень легень серозно-катаральним запаленням у частини 


\section{ВЕТЕРИНАРНА МЕДИЦИНА}

3 них, з яких виділені культури мікоплазм і бордетел, підтверджує наявність у стаді патогенних епізоотичних культур цих мікроорганізмів.

Значить у господарстві, в якому поросят відлучають від свиноматки в 45-60 діб перший i другий раз МВ вводять їм із 8-12-добового віку в носову порожнину з інтервалом в 7-8 діб і третій раз - у м'язи через 40-50 діб. БВ треба вводити поросятам із 8-20-добового віку, одержаним від свиноматок, нещеплених проти цього захворювання.

Таким чином, найвищі показники відсотків збережених і переданих на відгодівлю 3 найбільшою середньою живою масою тіла були серед поросят, одержаних від нещеплених БВ свиноматок, трохи нижчими - у поросят від щеплених проти нього свиноматок. Ще менші були показники у щеплених проти бордетельозу поросят від невакцинованих свиноматок і найнижчі - від вакцинованих. Кращими були показники серед поросят, одержаних від нещеплених БВ свиноматок, і щеплених $\mathrm{MB}$ та $\mathrm{MB}+$ БВ.

Результати застосування вакцин із атенуйованих «місцевих штамів» мікоплазм:

1. Комплекс на 108000 свиней в обороті за один рік. У трьох дослідах на поросятах випробували вакцину із атенуйованих «місцевих штамів» M. hyorhinis, M. arginini та A. laidlawii. Перший та другий рази вакцину вводили поросятам iз 7-10-добового віку із інтервалом у 7 діб у носову порожнину, а третій раз через 35-49 діб - у м'язи в дозах 3 мл, 4 та 5 мл відповідно. Кожне порося одержало близько 1,0-1,1.109 КУО мікоплазм.

У досліді 1480 поросятам щепили вакцину 3 M. hyorhinis, 731 - M. arginini i A. laidlawii та 1680 - M. hyorhinis, M. arginini i A. laidlawii. Y контролях було 653 голови, 1387 та 1397 голів відповідно. Поросят відняли від свиноматок в 30-добовому віці. Тому перші два рази вакцину щепили їм до відлучення на дільниці 3, а втретє - після відлучення i переведення для дорощування на дільницю 4. У кожному досліді за контрольних були поросята ідентичного віку із сусідніх секторів. У досліді 3 був ще один контроль невакциновані поросята однієї половини сектору і вакциновані - іншої його половини.

Поросята, щеплені вакциною із атенуйованих «місцевих штамів» M. hyorhinis, M. arginini i A. laidlawii, мали, порівняно із контрольними, значно кращі технологічні та економічні показники на дільниці 4: вищу на 6,6-7,7 \% збереженість та на 4,1-4,7 кг середню живу масу тіла і на 11,612,2 \% більшу кількість переданих на відгодівлю в технологічні терміни. Для технології господар- ства сприйнятливою є схема, за якої перший та другий рази вакцину вводять поросятам 7-18добового віку з інтервалом у 7 діб у носову порожнину, а втретє - через 35-49 діб (або близько до 30-добового терміну утримання на дільниці дорощування) в м'язи. Загальна доза мікоплазм близько $1,00.10^{9} \mathrm{KУO}$.

2. Спеціалізоване господарство на 12000 свиней в обороті за один рік. У досліді було 615 поросят. МВ щепили 412 поросят із 12-добового віку два рази через 7-8 діб у носову порожнину i один раз через 40 діб у м' язи по 3, 4 та 5 мл. Кожне порося одержало всього $1,3.10^{8}$ КУО мікоплазм. У контролі було 203 поросят. За тваринами встановили клінічне спостереження до передачі на відгодівлю (146-156 діб). Поросят відлучили від свиноматок у 45-добовому віці.

Вакцину готували із «місцевих штамів» (ГК29кі і ГК-30к M. hyorhinis, ГК-30л М. Arginini та ГК-31к A. laidlawii 15-20-го пересівів) згідно 3 наведеними методиками $(1,3,4,5)$. Їх виділили iз проб уражених серозно-катаральним запаленням легень поросят 2,5-4-місячного віку, убитих iз діагностичною метою у цьому ж господарстві. В асоціації із ними були також культури Corynebakterium pyogenes i Staphylococcus (St.) aureus.

У цьому господарстві через нестачу кормів раціон годівлі поросят був незбалансованим за поживністю та вмістом білку. Навіть у таких умовах серед щеплених поросят, порівняно $з$ контролем, була менша на 14,8 \% кількість відсталих у рості і на 7,1 \% загиблих та вища на 1,9 та 2,8 кг середня жива маса тіл під час передачі на дорощування та відгодівлю відповідно.

\section{Висновки:}

1. Порівняно 3 контролями, щеплені 5-валентною МВ поросята із 20-30-добового віку мали вірогідно більші показники середньої живої маси тіла, збереженості і технологічності в межах 2,78-3,3 кг, 5,6-9,4 \% і 28,4-31,3 \% відповідно за умови введення іiі в носову порожнину два рази із 7-8-добовим інтервалом за дві-три неділі до відлучення від свиноматок та втретє - у м'язи через 40-50 діб (групи дорощування). Загальна доза коливалася в межах 1,2-2,2.109 КУО мікоплазм.

2. У разі комплексного щеплення МВ і БВ одержали найкращі результати, коли перший i другий раз МВ вводили поросятам із 8-12добового віку в носову порожнину з інтервалом у 7-8 діб і третій раз - у м'язи через 40-50 діб, а БВ - поросятам із 8-20-добового віку, одержаних від свиноматок, нещеплених проти цього захворювання, у м'язи два рази із 7-8-добовим інтервалом. Порівняно з контролем, поросят щеп- 


\section{ВЕТЕРИНАРНА МЕДИЦИНА}

лених МВ, МВ+БВ і лише БВ передано більше на відгодівлю на $13,9 \%, 14,1$ і 7,8 \% із більшою живою масою тіла на 4,5 кг, 4,4 і 2,0 кг відповідно. Їх збереженість також була вищою на 4,0 \%, 3,1 і 1,0\% відповідно.

3. У комплексі на 108000 свиней в обороті за один рік із випробуваних трьох схем найкращі результати одержали в разі щеплення вакцини 3 «місцевих штамів» M. hyorhinis, M. arginini та A. laidlawii поросятам із 13-15-добового віку два рази із 7-добовим інтервалом у носову порожнину і один раз через 42-49 діб - у м'язи у випадку загальної дози мікоплазм близько $1,0.10^{9}$ КУО. Порівняно з контролем, за такої схеми загинуло і вимушено дорізано поросят на дільниці 4 (дорощуванні) менше на $8,1 \%$ і передано на відгодівлю більше на 13,0 \% із вищою середньою живою масою тіла на 8,5 кг. За найменшого третього інтервалу - 35-36 діб, який був ближче до терміну відняття від свиноматок (30 діб) ці показники становили $6,6 \%, 12,2 \%$ та 4,1 кг.

4. У спеціалізованому господарстві, де раціон

\section{БІБЛІОГРАФІЯ}

1. Андросик Н. Н. Изучение эффективности противомикоплазменной вакцинации // Ветеринария. - 1981. - №11. - С. 26-27.

2. Бердник В. П. Некоторые биологические свойства микоплазм свиней : дисс. на соиск. науч. степени к. вет. н. - М., 1973. -215 с.

3. Бердник В. П. Микоплазмоз свиней : дисс. на соиск. науч. степени д. вет. н. - М., 1991. - 616 с.

4. Бердник В. П. Приготування та випробування вакцини із мікоплазм. Повідомлення 1-6 // Вісник Полтавської державної аграрної академії. - 2010. № 3-4; 2011. - №1-2. - С. 34 .

5. Бублик О. О. Удосконалення методів культивування збудників мікоплазмозу свиней та розробка засобів специфічної профілактики : дис. на здобуття наук. ступеня к. вет. н. - Полтава, 2013. $127 \mathrm{c}$.

6. Методические указания по диагностике, профилактике и мерам борьбы с микоплазмозом свиней / [В. П. Бердник и соавт.]. - М., 1988. - 63 с.

7. Паутов Ю. Н. Этиологическое значение микоплазм и стафилококков при энзоотической пневмонии свиней : дисс. на соиск. науч. степени к. вет. н. - Усть-Каменогорск, 1989. - 142 с.

8. Experimental immunization against swine mycoplasmal pneumonia with living vaccine by nasal route / [H. Cheng - Lee, Ch. Jing - Hua, e.a.] // Yale годівлі поросят був незбалансованим за поживністю та вмістом білку, серед щеплених $\mathrm{MB}$ із «місцевих штамів», порівняно з контролем, була менша на 14,8 \% кількість відсталих у рості і на $7,1 \%$ загиблих та вища на 1,9 та 2,8 кг середня жива маса тіл під час передачі на дорощування та відгодівлю відповідно.

5. Випробування на поросятах вакцин із атенуйованих лабораторних штамів 5 видів мікоплазм і «місцевих культур» в умовах господарств із різними технологіями виробництва продукції показало, порівняно з контролями, підвищення рівнів середньої живої маси тіла, збереженості і технологічності, що свідчить за перспективність вибраного напряму досліджень із розробки засобів та методів боротьби з МС.

6. Показники імунологічної і економічної ефективності інактивованих і не інактивованих (атенуйованих) MB можна порівняти лише в досліді на поросятах у господарстві, неблагополучному i3 $\mathrm{MC}$.

J. Biol. Med. - 1983. - Vol. 56, №5-6. - P. 920-921.

9. Experimental studies on the immunity properties of living vaccine 168 against swine mycoplasmal pneumonia / [Jin Hongxica, Chu Jinghua, Mao Hong-xian e.a.] // Abstr. Posters 7 th Int. Congr. Int. Org. f. Mycoplasmology (IOM). - Baden near Vienna, Austria, June 2-9, 1988. - P. 138.

10. Himedia // CultureMedie Catalogue / Hi Media Laboratories. - 2007-08. - S. 1-374.

11. US Patent RE39494, I.Cl.:A61K39/02; A01N63/00; A61K39/00; A61K39/102; A61K39/116; $\mathrm{C} 12 \mathrm{~N} 1 / 00 ; \mathrm{C} 12 \mathrm{~N} 7 / 00$ Inactivated mycoplasma hyopneumoniae and uses therefor / Fitzgerald G. R. (Des Moines, IA, US) Welter J. C. (Wailufu, HI, US) Intervet Inc. (Millsboro, DE, US) ; заявл. 05.08. 2004 ; опубл. 27. 02. 2007.

12. US Patent Appl. 20050013823,I.Cl:(IPC1-7) : A61K039/02; A61K039/38; A61K039/00. One dose vaccination with Mycoplasma hyopneumoniae / Keich R. L. (Waterford, CT, US) Sabbadini L.G. (Mystic, CT, US) ; заявл. 12. 08.2004 ; опубл. 20. 01.2005.

13.US Patent Appl. 20100062018,I.Cl. A61K39/116; A61K39/02; A61P31/04. Mycoplasma hyopneumoniae bacterin vaccine. Chu H.-j. (Fort Dodge, IA, US), Li W. (Fort Dodge, IA, US), Xu Z. (Fort Dodge, IA, US), Wyeth (Madison, NJ, US) ; заявл. 16.11.2009 ; опубл. 11.03. 2010. 